\title{
Inducing Fungus-Resistance into Plants through Biotechnology
}

\author{
Shabir Hussain WANI \\ Central Institute of Temperate Horticulture, Srinagar, Jammu and Kashmir, 190007, India; shabirhussainwani@gmail.com
}

\begin{abstract}
Plant diseases are caused by a variety of plant pathogens including fungi, and their management requires the use of techniques like transgenic technology, molecular biology, and genetics. There have been attempts to use gene technology as an alternative method to protect plants from microbial diseases, in addition to the development of novel agrochemicals and the conventional breeding of resistant cultivars. Various genes have been introduced into plants, and the enhanced resistance against fungi has been demonstrated. These include: genes that express proteins, peptides, or antimicrobial compounds that are directly toxic to pathogens or that reduce their growth in situ; gene products that directly inhibit pathogen virulence products or enhance plant structural defense genes, that directly or indirectly activate general plant defense responses; and resistance genes involved in the hypersensitive response and in the interactions with virulence factors. The introduction of the tabtoxin acetyltransferase gene, the stilbene synthase gene, the ribosome-inactivation protein gene and the glucose oxidase gene brought enhanced resistance in different plants. Genes encoding hydrolytic enzymes such as chitinase and glucanase, which can deteriorate fungal cell-wall components, are attractive candidates for this approach and are preferentially used for the production of fungal disease-resistant plants. In addition to this, RNA-mediated gene silencing is being tried as a reverse tool for gene targeting in plant diseases caused by fungal pathogens. In this review, different mechanisms of fungal disease resistance through biotechnological approaches are discussed and the recent advances in fungal disease management through transgenic approach are reviewed.
\end{abstract}

Keywords: transgene, coat protein, RNA interference, chitinase, phytoalexins

\section{Introduction}

Plant pathogens are a real threat to worldwide agriculture. Significant yield losses due to fungal attacks occur in most of the agricultural and horticultural species. More than $70 \%$ of all major crop diseases are caused by fungi (Agrios, 2005). Crops of all kinds often suffer heavy losses. Fungal diseases are rated either the most important or second most important factor contributing to yield losses in major crops like rice (Lee et al., 2007), wheat (Huang and Gill, 2001), barley (Smith, 2002), cotton (Cui et al., 2000), groundnut (Mace et al., 2006), and grapevine (Dhekney et al., 2007). Fungal plant diseases are usually managed with the applications of chemical fungicides. For some diseases, chemical control is very effective, but it is often non-specific in its effects, killing beneficial organisms as well as pathogens, and it may have undesirable health, safety, and environmental risks (Manczinger et al., 2002). A promising method for protecting plants against diseases is constructing and employing pathogen-resistant cultivars. Although a number of resistant cultivars have been developed through breeding programs, these cultivars become obsolete in a short time due to the rapid evolution of the phytopathogens and the emergence of virulent forms capable to overcome the plant resistance. Breeders are often confronted with the issue of using a limited number of plants in their breeding programs, undesirable traits transferred together with the valuable resistance genes, and, in recent years, also with the depletion of potential gene sources. Control of diseases is a subject of great interest for biotechnologists. The most significant development in the area of varietal development for disease resistance is the use of the techniques of gene isolation and genetic transformation to develop transgenic resistance to fungal diseases. Improvements in genetic transformation technology have allowed the genetic modification of almost all important food crops like rice, wheat, maize, mustard, pulses and fruits. Genetic engineering technology has proved to be beneficial in managing viral (Wani and Sanghera, 2010) and bacterial (Jube and Borthakur, 2007; Sanghera et al., 2009) diseases in plants. The advances in gene engineering technologies and the understanding of the molecular nature of plant protection mechanisms have provided means for developing principally new strategies of plant disease control, in addition to the traditional approaches based on employing chemicals or classical breeding schemes. Biotechnology will enhance our understanding of the mechanisms that control plant's ability to recognize and defend itself against disease caused by fungi (Punja, 2007). The integration of biotechnology with traditional agricultural practices will be the backbone for sustainable agriculture

\section{Plant biotechnology and fungal disease management}

Plant biotechnology is a precise process in which special techniques are used to develop molecular-and cellular- 
based technologies to improve plant productivity, quality and health; to improve the quality of plant products; or to prevent, reduce or eliminate constraints to plant productivity caused by biotic and abiotic stresses (Azhaguvel et al., 2006). Plant biotechnology involves the modification of plant performance for a particular purpose. Genome segments from plant pathogenic fungi are widely used as vectors with genes inserted to make transgenic plants. This is of paramount importance to ensure efficacy and genetic integrity of the product and to protect intellectual property. This can be achieved in a number of ways including:

a. Increasing or decreasing the expression of several genes that are naturally present in an organism.

b. Transferring genes between individuals of the same or different species.

Genetic engineering refers to artificial techniques capable of transferring genes from other organisms directly to recipient organisms (Gold, 2003). The techniques of genetic engineering can be used to manipulate the genetic material of a cell in order to produce a new characteristic in an organism. Genes from plants, and microbes can be recombined and introduced into the living cells of any of these organisms (Azhaguvel et al., 2006). Transgenic recombinant plants are generated by adding one or more genes to a plant's genome and the techniques are frequently called transformation (Newell, 2000). Transgenic recombinant plants are identified as a class of genetically modified organism (GMO); usually, only transgenic plants created by direct DNA manipulation are given much attention for public discussions (Osusky, 2004). Genetic engineering has the potential to provide a cornucopia of beneficial plant traits, particularly an enhanced ability to withstand or resist attack by plant's pathogens (Chenault et al., 2005; Punja, 2007). New approaches to plant disease control are particularly important for pathogens that are difficult to control by the existing methods. Genetic engineering can help farmers to increase crop yields and feed even more people (Amalu, 2004). The percentage of GMO plant resistant to diseases is approximately about $2 \%$ of total cultivated GMO plants (Gold, 2003).

\section{Mechanism disease resistant genes on plant}

Genetic engineering for fungal resistance has been limited. But several new advances in this area now present an optimistic outlook. Many reports (Makandar et al., 2006; Yang et al., 2009) show positive results relative to transgenic plants, expressing genes for fungal disease resistance (Tab. 1). Depending upon the mechanism of plant disease resistance, the transgenic plants have been grouped into the following categories:

(i) Pathogenesis-related (PR) proteins

PR protein genes appear to be a very potential source for candidate genes for fungal resistance. Van Loon and van Strein (1999), showed that a set of proteins is induced in tobacco plants after tobacco mosaic virus infection. Host plants contribute an enormous number of diseases resistance genes such as those encoding pathogenesis-related (PR) proteins, which have been used against fungal diseases (Van Loon and Van Strien, 1999). PR proteins were shown to be induced not only by pathogens but also by wounding, fungal cell wall elicitors, ethylene, UV light, heavy metals, etc. PR proteins are induced during hypersensitive response (HR) and also during systemic acquired resistance (SAR) and therefore are thought to have a role in natural defense or resistance of plants against pathogens. These proteins may play a direct role in defense by attacking and degrading pathogen cell wall components (Fig. 1). PR proteins that exhibit antifungal activity, including osmotin-and thaumatin-like proteins (TLP), and some uncharacterized PR proteins have been engineered into crop plants. The PR-5 proteins induce fungal cell leakiness, presumably through a specific interaction with the plasma membrane that results in the formation of transmembrane pores (Kitajima and Sato, 1999). Thaumatin-like proteins are also expressed in plants as response to a range of stress conditions and were demonstrated to have antifungal activity in vitro against several pathogens, including Botrytis, Fusarium, Rhizoctonia, and Sclerotinia (Koiwa et al., 1997). When expressed in transgenic potato, osmotin was shown to delay the expression of disease symptoms caused by Phytophthora infestans. Other pathogenesis-related proteins/peptides include osmotin, thionins and lectins (Florack and Stiekema, 1994).

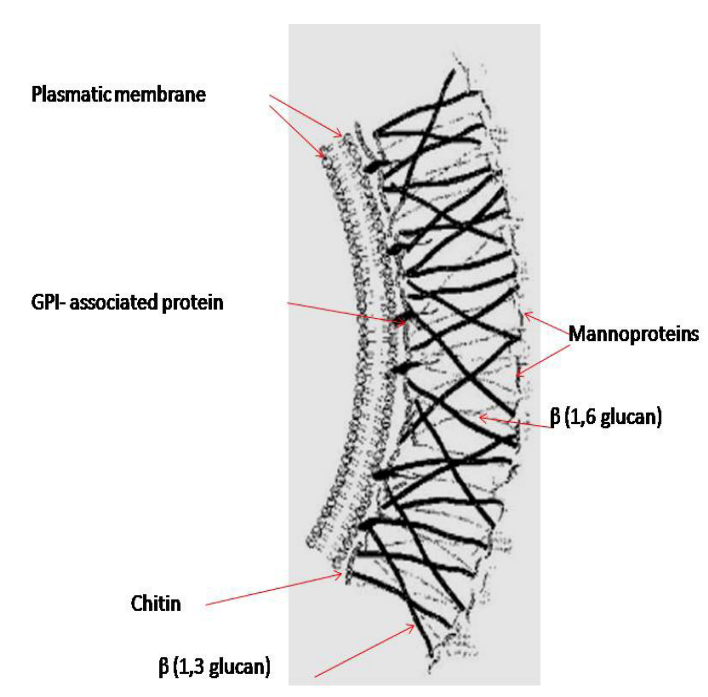

Fig. 1. Fungal cell wall (Selitrennikoff, 2001)

\section{(ii) Antifungal proteins}

Introduction of the chitinase gene in tobacco and rice has been shown to enhance fungal resistance in plants (Lee and Raikel, 1995; Nishizawa et al., 1999). Chitinase 
Tab. 1. Transgenic plants for fungal disease resistance

\begin{tabular}{|c|c|c|c|c|}
\hline Transgene & Source & Target species & Pathogen & Reference \\
\hline $\begin{array}{c}\text { Vst1 (Stilbene } \\
\text { (resveratrol) synthase) }\end{array}$ & Vitis vinifera & Nicotiana tabacum & Botrytis cinerea & Hain et al. (1993) \\
\hline Aglul, RCH10 & Alfalfa, Rice & Nicotiana tabacum & Cercospora nicotianae & Zhu et al. (1994) \\
\hline PR-3(I) & Rice & Rice & Rhizoctonia solani & Lin et al. (1995) \\
\hline Aglul, RCH10 & Alfalfa, Rice & Alfalfa & $\begin{array}{l}\text { Phytophthora megasperma } \\
\text { f.sp.medicaginis (Pmm) }\end{array}$ & Masoud et al., 1996 \\
\hline$P R-3(I)$ & Rice & Cucumber & Botrytis cinerea & Tabei et al. (1998) \\
\hline $\begin{array}{c}V_{s t 1} \text { (Stilbene } \\
\text { (resveratrol) synthase) pss } \\
\text { (pinosylvin synthase) }\end{array}$ & $\begin{array}{l}\text { Vitis vinifera, } \\
\text { Pinus sylvestris }\end{array}$ & $\begin{array}{l}\text { Hordeum vulgare, } \\
\text { Triticum aestivum }\end{array}$ & $\begin{array}{c}\text { Botrytis cinerea; Puccinia } \\
\text { recondita f.sp. tritici \& } \\
\text { Stagonospora (Septoria) } \\
\text { nodorum }\end{array}$ & $\begin{array}{l}\text { Leckband and Lorz (1998); } \\
\text { Serebriakova et al. (2005) }\end{array}$ \\
\hline$R C C 2$ & Rice & Grape vine & $\begin{array}{l}\text { Uncinula necator, } \\
\text { Elisinoe ampelina }\end{array}$ & Yamamoto et al. (2000) \\
\hline Synthetic $D 4 E 1$ & Cecropia (insect) & Nicotiana tabacum & Colletotrichum destructivum & Cary et al. (2000) \\
\hline AiiA & Bacillus & Solanum tuberosum & $\begin{array}{c}\text { Pectobacterium } \\
\text { (Erwinia) carotovora }\end{array}$ & Dong et al. (2001) \\
\hline RC7 chitinase PR-3 & Oryza sativa & Oryza sativa & Rhizoctonia solani. & Datta et al. (2001) \\
\hline gf-2.8 (oxalateoxidase) & Triticum aestivum & Glycine max & Sclerotinia sclerotiorum & Cober et al. (2003) \\
\hline $\operatorname{Cry} 1 \mathrm{Ab}$ (Bt toxin) & Bacillus thuringiensis & Zeamays & Fusarium spp & $\begin{array}{l}\text { Clements et al. (2003); } \\
\text { Hammond et al. (2004) }\end{array}$ \\
\hline Rpi-blb2 (NB-LRR) & Solanum bulbocastanum & Solanum tuberosum & Phytophthora infestans & $\begin{array}{l}\text { Van Der Vossen } \\
\text { et al. }(2003,2005)\end{array}$ \\
\hline$V f(C f)$ & Malus floribunda & Malus domestica & Venturia inaequalis & Belfanti et al. (2004) \\
\hline gf-2.8 (oxalate oxidase) & Triticum aestivum & $\begin{array}{l}\text { Populus } \\
\text { euramericana }\end{array}$ & Septoria musiva & Liang et al. (2004) \\
\hline Rchit & Rice & Pigeon pea & & Kumar et al. (2004) \\
\hline $\begin{array}{c}\text { 9f- } 2.8 \text { (oxalate oxidase) } \& \\
\text { TaPERO (peroxidase) }\end{array}$ & Triticum aestivum & Triticum aestivum & Blumeria graminis f.sp. tritici & Altpeter et al. (2005) \\
\hline Chit & French Bean & Cotton & Verticillium dabliae & Masoud et al. (2005) \\
\hline Chill (chitinase) Tlp (PR-4) & Oryza sativa & Oryzasativa & Rhizoctonia solani & Kalpana et al. (2006) \\
\hline NPRI & Arabidopsis thaliana & Triticum aestivum & Fusarium graminearum & Makandar et al. (2006) \\
\hline KP4 & $\begin{array}{l}\text { Virus infecting } \\
\text { Ustilago maydis }\end{array}$ & Triticum aestivum & Tilletia caries & Schlaich et al. (2006) \\
\hline Gfzhd101 & Clonostachys rosea & Zea mays & Fusarium graminearum & Igawa et al. (2007) \\
\hline Synthetic $D 4 E 1$ & Cecropia (insect) & $\begin{array}{l}\text { Gossypium } \\
\text { hirsutum }\end{array}$ & Thielaviopsis basicola & Rajasekaran et al. (2007) \\
\hline Chi 18 (chitinase) & Solanum tuberosum & Raphanus sativus Linn & Rhizoctonia solani & Yang et al. (2009) \\
\hline
\end{tabular}

enzyme degrades the major constituents of the fungal cell wall (chitin and $\alpha-1,3$ glucan). Coexpression of chitinase and glucanase genes in tobacco and tomato plants confers a higher level of resistance than that imparted by either gene alone. Use of genes for ribosome-inactivating proteins (RIP), along with chitinase, has also shown synergistic effects. A radish gene encoding antifungal protein 2 (Rs-AFP2) was expressed in transgenic tobacco and resistance to Alternaria longipes was observed (Broekaert $e t$ al., 1995). Transgenic tobacco plants harbouring human lysozyme gene showed enhanced resistance against the fungus Erysiphe cichoracearum-both conidia formation and mycelia growth were reduced, and the size of the colony was diminished (Fig. 2) (Nakajima et al., 1997). (iii) Phytoalexins

The low molecular weight compounds, such as phytoalexins, possess antimicrobial properties and have been implicated in imparting plant resistance to fungal and bacterial pathogens (Leckband and Lorz, 1998). Active oxygen species (AOS), including hydrogen peroxide, also play an important role in plant defense responses to pathogen infection.Transgenic potato plants expressing an $\mathrm{H}_{2} \mathrm{O}_{2}$-generating fungal gene for glucose oxidase were found to have elevated levels of $\mathrm{H}_{2} \mathrm{O}_{2}$ and enhanced levels of resistance both to fungal and bacterial pathogens particularly to the verticillium wilt pathogen (Wu et al., 1995). Further, overexpression of defense-response genes in transgenic plants has provided enhanced resistance to a variety of fungal pathogens (Muehlbauer and Bushnell, 2003). For example, transgenic wheat lines carrying a bar- 


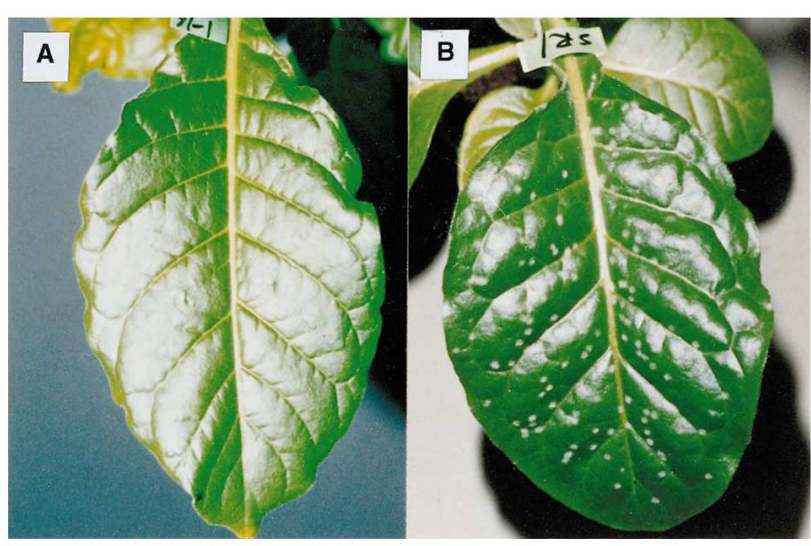

Fig. 2. Enhanced resistance of transgenic tobacco plants against E. cichoracearum; A. The transgenic tobacco plant, NT-7, which produced the human lysozyme; B. Wild-type tobacco 'SR1' (Nakajima et al., 1997)

ley-seed class II chitinase exhibited enhanced resistance to powdery mildew (Bliffeld et al., 1999; Oldach et al., 2001). Varying levels of resistance towards powdery mildew were observed in transgenic wheat lines carrying a barley chitinase or a barley $\beta$-1, 3-glucanase (Bieri et al., 2003). With respect to fusarium head blight $(\mathrm{FHB})$ a transgenic wheat line carrying a rice $t / p$ and a line carrying a combination of a wheat $\beta$-1, 3-glucanase and chitinase exhibited delayed symptoms of FHB in greenhouse trials (Chen et al., 1999; Anand et al., 2003). In addition, transgenic Arabidopsis plants carrying an overexpressed Arabidopsis thionin have exhibited increased resistance to F. oxysporum (Epple et al., 1997). Transgenic wheat expressing the Arabidopsis NPR 1 gene, a gene that regulates defense responses, was shown to exhibit a high level of resistance to FHB in greenhouse evaluations (Makandar et al., 2006).

\section{(iv) Antimicrobial Proteins}

An antimicrobial protein with homology to lipid transfer protein was shown to reduce the development of Botrytis cinerea when expressed in transgenic geranium (Bi et al., 1999). Antimicrobial peptides have been synthesized in the laboratory to produce smaller (10-20 amino acids in length) molecules that have enhanced potency against fungi (Cary et al., 2000). The overexpression of defensins and thionins in transgenic plants was demonstrated to reduce the development of several different pathogens, including Alternaria, Fusarium, and Plasmodiophora, and provided resistance to Verticillium on potato under field conditions (Gao et al., 2000).

\section{(v) Plant ribosome-inactivating proteins and other peptides}

Ribosome-inactivating proteins are plant enzymes that have $28 \mathrm{~S}$ rRNA $N$-glycosidase activity, which depending on their specificity can inactivate conspecific or foreign ribosomes, thereby shutting down protein synthesis. Plant RIPs inactivate foreign ribosomes of distantly related spe- cies and of other eukaryotes including fungi. A purified RIP from barley inhibits growth of several fungi in vitro. Tobacco plants constitutively expressing a RIP encoding DNA sequence of barley showed better resistance to $R$. solani (Logemann et al., 1993). Resistance levels improved when RIP was used in combination with either PR2 or PR3.

In addition, a synthetic cationic peptide chimera (cecropin-melittin) with a broad-spectrum antifungal activity has been produced (Osusky et al., 2000). When expressed in transgenic potato and tobacco, these synthetic peptides have provided enhanced resistance against a number of fungal pathogens, including Colletotrichum, Fusarium, and Phytophthora. These peptides may demonstrate lytic activity against fungal hyphae, inhibit cell wall formation, and (or) enhance membrane leakage. The ability to create synthetic recombinant and combinatorial variants of peptides that can be rapidly screened in the laboratory could provide additional opportunities to engineer resistance to a range of pathogens simultaneously (Dhekney et al., 2007). MsrA2 peptide was shown to control Fusarium head blight (FHB) of wheat and barley grains caused by Fusarium graminearum. Trichothecenes genes-the virulence factors produced by the fungus-were introducing into wheat in order to increase the FHB defense mechanism in wheat spikes and reduced or prevented the initial infection (Osusky, 2004).

\section{(vi) Resistance genes (R-gene)}

The $R$-gene products that have been cloned from tomato, tobacco, rice, flax, Arabidopsis, and several other plant species shared one or more similar motifs: a serine or threonine kinase domain, a nucleotide binding site, a leucine zipper, or a leucine-rich repeat region, all of which may contribute to recognition specificity (Takken and Joosten, 2000). The plant's resistance $R$-gene product acts as a signaling receptor for the pathogen's avirulence ( $A v r$ ) gene product in the presence of resistance-regulating factors such as RAR1 and SGT1, leading to a form of cell death termed hypersensitive response (Rowland et al., 2005). $A V R$ genes were isolated from $B g h$, a representative of the powdery mildews as the third major group of obligate biotrophic parasites (Ridout et al., 2006). The results indicated that the mildew fungus has a repertoire of $A V R$ genes, which may function as effectors and contribute to parasite virulence. Multiple copies of related but distinct $A V R$ effector paralogues might enable populations of $B g h$ to rapidly overcome host $R$-genes while maintaining virulence. A combination of several interacting genes, similar to that for the antifungal proteins, will likely to be required. An enhanced understanding of $R$-gene structure and function could, however, make it possible to modify functional domains in the future to tailor $R$-genes for use in providing broad-spectrum resistance to diseases in transgenic plants (Dempsey et al., 1998). 
18

\section{(vii) Degradation of Phytotoxic metabolites}

The plant cell wall acts as a barrier for the penetration of fungal pathogens and numerous strategies have evolved among plant pathogens to overcome this (Walton, 1994). Production of phytotoxic metabolites of fungal pathogens, such as mycotoxins and oxalic acid, have been shown to facilitate infection of host tissues following cell death. Degradation of these compounds by enzymes expressed in transgenic plants could provide an opportunity to enhance resistance to disease. Expression of a trichothecene degrading enzyme from Fusarium sporotrichioides in transgenic tobacco reduced plant tissue damage and enhanced seedling emergence in the presence of the trichothecene (Muhitch et al., 2000). Their activity on the substrate of oxalic acid results in the production of $\mathrm{CO}_{2}$ and $\mathrm{H}_{2} \mathrm{O}_{2}$, which latter can induce defense responses in the plant and enhance strengthening of cell walls. Expression of oxalate oxidase in transgenic hybrid poplar enhanced the resistance to Septoria, while oxalate decarboxylase expression enhanced resistance of tomato to Sclerotinia sclerotiorum (Thompson et al., 1995). These results indicate that the inactivation of specific pathogen virulence factors, such as toxins, by gene products expressed in transgenic plants has the potential to reduce the development of specific fungal pathogens.

\section{$R N A$ silencing}

RNA-mediated gene silencing is being tried as a reverse tool for gene targeting in plant diseases caused by fungal, bacterial and viral pathogens (Sanghera et al., 2009). Homology-based gene silencing induced by transgenes (co-suppression), antisense RNA, or dsRNA has been demonstrated in many plant pathogenic fungi, including Cladosporium fulvum (Hamada and Spanu, 1998), Magnaporthae oryzae (Kadotani et al., 2003), Venturia inaequalis (Fitzgerald et al., 2004), Neurospora crassa (Goldoni et al., 2004), Aspergillus nidulans (Hammond and Keller 2005), and Fusarium graminearum (Nakayashiki et al., 2005). Fitzgerald and colleagues (2004), using hairpin-vector technology, have been able to trigger simultaneous high frequency silencing of a green fluorescent protein $(G F P)$ transgene and an endogenous trihydroxynaphthalene reductase gene $(T H N)$ in $V$. inaequalis. The GFP transgene acted as an easily detectable visible marker, while the trihydroxynaphthalene reductase gene $(T H N)$ played a role in melanin biosynthesis. Nakayashiki et al. (2005) developed a protocol for silencing the $m p g l$ and polyketide synthaselike genes. The mpgl gene is a hydrophobin gene that is essential for pathogenicity, as it acts as a cellular relay for adhesion and trigger for the development of appressorium (Talbot et al., 1996). Nakayashiki et al. (2005) were successful in silencing the above-mentioned genes to varying degrees by pSilent-1-based vectors in $70-90 \%$ of the transformants. Ten to fifteen percent of the silenced transformants exhibited almost "null phenotype." This vector was also efficiently able to silence a GFP reporter in another ascomycete fungus, Colletotrichum lagenarium.

\section{Conclusions and future prospects}

After discussing the various mechanisms involved in the plant resistance to fungal diseases, it can be concluded that several strategies have emerged for developing crop varieties resistant to pathogens. Strategies include the manipulation of resistance by expression of PR proteins, antifungal peptides and manipulation of biosynthesis of phytoalexins. However, in these cases the observed resistance was not absolute and was restricted to a limited number of fungi. As to the antifungal compounds strategy to be successful in the long term, the level of resistance in transgenic plants should be increased and its range should be broadened by isolating new genes and by testing new gene combinations. Resistance genes involved in R-Avr interaction have been isolated from many crops and fungus-resistant transgenics are being produced by incorporating the $R$-genes in susceptible plants within a genus or a family, or even outside the family. Arabidopsis, with its whole genome sequenced, will prove to be an increasingly useful system in decoding the functions of various defense genes and become pathways for isolation of more and more R-genes in Arabidopsis and their orthologous counterparts in other crop species. Biotechnology provides new opportunities to build disease resistance into plants. Such developments may reduce the demand for fungicides. Transgenic plants with enhanced disease resistance can become a valuable component of a disease management program in the future. Thus, biotechnology in addition to traditional breeding techniques will help minimize losses due to biotic stresses and render a more sustainable agriculture.

\section{References}

Agrios, G. N. (2005). Plant Pathology. Fifth edition, Academic Press. New York, p. 633.

Altpeter, F., A. Varshney, O. Abderhalden, D. Douchkov, C. Sautter, J. Kumlehn, R. Dudler and P. Schweizer (2005). Stable expression of a defense-related gene in wheat epidermis under transcriptional control of a novel promoter confers pathogen resistance. Plant Mol. Biol. 57:271-283.

Amalu, C. (2004). Plant biotechnology and food crop development in Sub-Saharan Africa. Technol. Soc. 26:537550.

Anand, A., T. Zhou, H. N. Trick, B. S. Gill, W. W. Bockus and S. Muthukrishnan (2003). Greenhouse and field testing of transgenic wheat plants stably expressing genes for thaumatin-like protein, chitinase and glucanase against Fusarium graminearum. J. Exp. Bot. 54:1101-1111.

Azhaguvel, P., D. Vidya, A. Sharma and R. K. Varshney (2006). Methodological advancement in molecular markers to delimit the gene(s) for crop improvement, pp. 460-469. 
In: Floriculture, Ornamental and Plant Biotechnology. Advances and Topical Issues. Teixera da Silva, J. (Eds.) Global Science Books, London, UK.

Belfanti, E., D. E. Silfverberg, S. Tartarini, A. Patocchi, M. Barbieri, J. Zhu, B. A. Vinatzer, L. Gianfranceschi, C. Gessler, and S. Sansavini (2004). The HcrVf2 gene from a wild apple confers scab resistance to a transgenic cultivated variety. Proc. Nat. Acad. Sci.101:886-890.

Bi, Y. M., B. Cammue, P. Goodwin and P. K. Saxena (1999). Resistance of Botrytis cinerea in scented geranium transformed with a gene encoding the antimicrobial protein Ace-AmP1. Plant Cell Rep. 18:835-840.

Bieri, S., I. Potrykus and J. Futterer (2003). Effects of combined expression of antifungal barley seed proteins in transgenic wheat on powdery mildew infection. Mol. Breed. 11:37-48.

Bliffeld, M., J. Mundy, I. Potrykus and J. Futterer (1999). Genetic engineering of wheat for increased resistance to powdery mildew disease. Theor. Appl. Genet. 98:1079-1086.

Broekaert, W. F., F. R. G. Terras, B. P. A. Cammue and R. W. Osborn (1995). Plant defensins: novel antimicrobial peptides as components of the host defense system Plant Physiol. 108:1353-1358.

Cary, J. W., K. Rajasekaran, J. M. Jaynes and T. E. Cleveland (2000). Transgenic expression of a gene encoding a synthetic antimicrobial peptide results in inhibition of fungal growth in vitro and in planta. Plant Sci. 154:171-181.

Chen, W. P., P. D. Chen, D. J. Liu, R. Kynast, B. Friebe, R. Velazhahan, S. Muthukrishnan and B. S. Gill (1999). Development of wheat scab symptoms is delayed in transgenic wheat plants that constitutively express a rice thaumatin-likeprotein gene. Theor. Appl. Genet. 99:755760 .

Chenault, K., H. A. Melouk and M. E. Payton (2005). Genomics, molecular genetics and biotechnology. Crop Sci. 45:511-515.

Clements, M. J., K. W. Campbell, C. M. Maragos, C. Pilcher, J. M. Headrick, J. K. Pataky and D. G. White (2003). Influence of Cryl $\mathrm{Ab}$ protein and hybrid genotype on fumonisin contamination and fusarium ear rot of corn. Crop Sci. 43:1283-1293.

Cober, E. R., S. Rioux, I. Rajcan, P. A. Donaldson and D. H. Simmonds (2003). Partial resistance to white mold in a transgenic soybean line. Crop Sci. 43:92-95.

Cui, Y., A. A. Bell, O. Joost and C. Magill (2000). Expression of potential defense response genes in cotton. Physiol. Mol. Plant Pathol. 56:25-31.

Datta, K., J. Tu, N. Oliva, I. Ona, R. Velazhahan, T. W. Mew, S. Muthukrishnan and S. K. Datta (2001). Enhanced resistance to sheath blight by constitutive expression of infectionrelated rice chitinase in transgenic elite indica rice cultivars. Plant Sci.160:405-414.

Dempsey, D. A., H. Silva and D. F. Klessig (1998). Engineering disease and pest resistance in plants. Trends Microbiol.
54:54-61.

Dhekney, S. A., Z. T. Li., M. An Aman, M. Dutt, J. Tattersall and D. J. Gray (2007). Genetic transformation of embryogenic cultures and recovery of transgenic plants in Vitis vinifera, Vitis rotundifolia and Vitis hybrids. Acta Hort. 738:743748.

Dong, Y. H., L. Wang, J. L. Xu, H. B. Zhang, X. F. Zhang and L. H. Zhang (2001). Quenching quorum-sensing-dependent bacterial infection by an $\mathrm{N}$-acyl homoserine lactonase. Nature 411:813-817.

Epple, P., K. Apel and H. Bohlmann (1997). Overexpression of an endogenous thionin enhances resistance of Arabidopsis against Fusarium oxysporum. Plant Cell 9:509-520.

Fitzgerald, A., J. A. V. Kha and K. M. Plummer (2004). Simultaneous silencing of multiple genes in the apple scab fungus Venturia inaequalis, by expression of RNA with chimeric inverted repeats. Fungal Genet. Biol. 41:963-971.

Florack, D.E. A. and W.J. Stiekema (1994). Thionins: properties, possible biological roles and mechanisms of action. Plant Mol. Biol. 26:25-37.

Gao, A., S. M. Hakimi, C. A. Mittanck, Y. Wu, B. M. Woerner, D. Stark, D. Shah, J. Liang and C. Rommens (2000). Fungal pathogen protection in potato by expression of a plant defensin peptide. Nat. Biotechnol. 18:1307-1310.

Gold, R. (2003). Exclusive rights in life: biotechnology, genetic manipulation, and intellectual property rights. In: Genetic Transformation of Plants. Jackson, J. and Linskens, H., Eds. Springer. Germany 23:2-6.

Goldoni, M., G. Azzalin, G. Macino and C. Cogoni (2004). Efficient gene silencing by expression of double stranded RNA in Neurospora crassa. Fungal Genet. Biol. 41:10161024.

Hain, R., H. J. Reif, E. Krause, R. Langebartels, H. Kindl, B. Vornam, W. Wiese, E. Schmelzer, P. Schreier, R. Stöcker and K. Stenzel (1993). Disease resistance results from foreign phytoalexin expression in a novel plant. Nature 361:153156.

Hamada, W. and P. D. Spanu (1998). Co-suppression of the hydrophobin gene $H c f-1$ is correlated with antisense RNA biosynthesis in Cladosporium fulvum. Mol. Gen. Genet. 259:630-638.

Hammond, B. G., K. W. Campbell, C. D. Pilcher, T. A. Degooyer, A. E. Robinson, B. L. McMillen, S. M. Spangler, S. G. Riordan, L. G. Rice and J. L. Richard (2004). Lower fumonisin mycotoxin levels in the grain of $\mathrm{Bt}$ corn grown in the United States in 2000-2002. J. Agric. Food Chem. 52:1390-1397.

Hammond, T. M. and N. P. Keller (2005). RNA silencing in Aspergillus nidulans is independent of RNA-dependent RNA polymerase. Genetics 169:607-617.

Igawa, T., N. Takahashi-Ando, N. Ochiai, S. Ohsato, T. Shimizu, T. Kudo, I. Yamaguchi and M. Kimura (2007). Reduced contamination by the Fusarium mycotoxin zearalenone 
20

in maize kernels through genetic modification with a detoxification gene. Appl. Environ. Microbiol. 73:16221629.

Jube, S. and D. Borthakur (2007). Expression of bacterial genes in transgenic tobacco: methods, applications and future prospects. Electron. J. Biotechnol.10:452-467.

Kadotani, N., H. Nakayashiki, Y. Tosa and S. Mayama (2003). RNA silencing in the pathogenic fungus Magnaporthe oryzae. Mol. Plant-Microbe Interact. 16:769-776.

Kalpana, K., S. Maruthasalam, T. Rajesh, K. Poovannan, K. K. Kumar, E. Kokiladevi, J. A. J. Raja, D. Sudhakar, R. Velazhahan, R. Samiyappan and P. Balasubramanian (2006). Engineering sheath blight resistance in elite indica rice cultivars using genes encoding defense proteins. Plant Sci. 170:203-215

Kitajima, S. and F. Sato (1999). Plant pathogenesis-related proteins: molecular mechanisms of gene expression and protein function. J. Biochem. 125:1-8.

Koiwa, H., H. Kato, T. Nakatsu, J. Oda and F. Sato (1997). Purification and characterization of tobacco pathogenesisrelated protein PR-5d, an antifungal thaumatin like protein. Plant Cell Physiol. 38:783-91.

Kumar, S. M., B. K. Kumar, K. K. Sharma and P. Devi (2004). Genetic transformation of pigeon pea with rice chitinase gene. Plant Breed.123:485-489.

Leckband, G. and H. Lorz (1998). Transformation and expression of a stilbene synthase gene of Vitis vinifera L. in barley and wheat for increased fungal resistance. Theor. Appl. Genet. 96:1004-1012.

Lee, H. I. and N. V. Raikel (1995). Prohevein is poorly processed but shows enhanced resistance to a chitin-binding fungus in transgenic tomato plants. Braz. J. Med. Biol. Res. 28:743750 .

Liang, H., C. A. Maynard, R. D. Allen and W. A. Powell (2004). Increased Septoria musiva resistance in transgenic hybrid poplar leaves expressing a wheat oxalate oxidase gene. Plant Mol. Biol. 45:619-629.

Lin, W., C.S. Anuratha and K. Datta (1995). Genetic engineering of rice for resistance to sheath blight. Biotechnol. 13:686691.

Logemann, J., G. Jach, H. Tommerup, J. Mundy and J. Schell (1993). Expression of a barley ribosome-inactivating protein leads to increased fungal protection in transgenic tobacco plants. Biotechnol. 10:305-308.

Mace, E. S., D. Phong, H. Upadhyaya, S. Chandra and J. H. Crouch (2006). SSR analysis of cultivated groundnut (Arachis hypogaea L.) germplasm resistant to rust and late leaf spot diseases. Euphytica 152:317-330.

Makandar, R., J. S. Essig, M. A. Schapaugh, H. N. Trick and J. Shah (2006). Genetically engineered resistance to Fusarium head blight in wheat by expression of Arabidopsis NPRI. Mol. Plant-Microbe Interact. 19:123-129.

Manczinger, L., Z. Antal and L. Kredics (2002). Ecophysiology and breeding of mycoparasitic Trichoderma strains (a review). Acta Microbiol. Immunol. Hungarica. 49:1-14.

Masoud, S. A., Q. Zhu, C. Lamb and R. A. Dixon (1996). Constitutive expression of an inducible $\beta-1,3-$ Glucanase in alfalfa reduces disease severity caused by the oomycete pathogen Phytophthora megasperma f. sp. medicaginis, but does not reduce severity of chitin-containing fungi. Transgenic Res. 5:313-323.

Masoud, T., M. Mojtaba and G. Behzad (2005). Agrobacteriummediated transformation of cotton (Gossypium hirsutum) using a heterologous bean chitinase gene. Plant Cell Tiss. Org. Cult. 83:83-96.

Muehlbauer, G. J. and W. R. Bushnell (2003). Transgenic approaches to resistance. In Fusarium head blight of wheat and barley, eds. K. J. Leonard and W.R. Bushnell American Phytopathological Society Press, St. Paul, MN.

Muhitch, M. J., S. P. McCormick, N. J. Alexander and T. M. Hohn (2000). Transgenic expression of the TRI 101 or PDR 5 gene increases resistance of tobacco to the phytotoxic effects of the trichothecene 4:15-diacetoxyscirpenol. Plant Sci. 157:201-207.

Nakajima, H., T. Muranaka, F. Ishige, K. Akutsu and K. Oeda (1997). Fungal and bacterial disease resistance in transgenic plants expressing human lysozyme Plant Cell Rep. 16:674679.

Nakayashiki, H., S. Hanada, B. Q. Nguyen, N. Kadotani, Y. Tosa and S. Mayama (2005). RNA silencing as a tool for exploring gene function in ascomycete fungi. Fungal Genet. Biol. 42:275-283.

Newell, C. A. (2000). Plant transformation technology: developments and applications. Mol. Biotechnol. 16:53-65.

Nishizawa, Y. Z., K. Nishio, M. Nakazono, E. Soma, M. U. Nakajima and T. Hibi (1999). Enhanced resistance to blast (Magnaporthe grisea) in transgenic japonica rice by constitutive expression of rice chitinase. Theor. Appl. Genet. 99:383-390

Oldach, K. H., D. Becker and H. Lorz (2001). Heterologous expression of genes mediating enhanced fungal resistance in transgenic wheat. Mol. Plant-Microbe Interact. 14:832838.

Osusky, M. (2004). Transgenic Research. Springer, Germany. 13:181-190.

Osusky, M., G.Zhou, L. Osuska, R. Hancock and S. Misra (2000). Transgenic plants expressing cationic peptide chimeras exhibit broad-spectrum resistance to phytopathogens. Nat. Biotechnol. 18:1162-1166.

Punja, Z. K. (2007). Biotechnology and Plant Disease Management. Pub Hardback. New York. p. 580.

Rajasekaran, K., J. W. Cary, J. M. Jaynes and T. E. Cleveland (2007). Disease resistance conferred by the expression of a gene encoding a synthetic peptide in transgenic cotton (Gossypium hirsutum L.) plants. Plant Biotechnol. J. 3:545554. 
Ridout, P., O. Porritt, S. Sacristan, D. Jones and K. Brown (2006). Multiple a virulence paralogues in cereal powdery mildew fungi may contribute to parasite fitness and defeat of plant resistance. Plant Cell. 18:2402-2414.

Rowland, O., A. Ludwig, C. J. Merrick, F. Baillieul, F. E. Tracy, W. E. Durrant, V. Nekrasov, K. Sjolander and H. Y. Yoshioka (2005). Functional analysis of Avr9/Cf-9 rapidly elicited genes identifies a protein kinase, $\mathrm{ACIK} 1$, that is essential for full Cf-9-dependent disease resistance in tomato. Plant Cell. 17:295-310

Sanghera, G. S., M. S. Gill, S. S. Gosal and S. H. Wani (2009). RNA Interference: Its Concept and application in crop plants. In: Biotechnology: Cracking new pastures. Malik C. P. MD Publications, New Delhi, India. p.33-78

Schlaich, T., B. M. Urbaniak, N. Malgras, E. Ehler, C. Birrer, L. Meier and C. Sautter (2006). Increased field resistance to Tilletia caries provided by a specific antifungal virus gene in genetically engineered wheat. Plant Biotechnol. J. 4:63-75.

Serebriakova, L., K. H. Oldach and H. Lorz (2005). Expression of transgenic stilbene synthases in wheat causes the accumulation of unknown stilbene derivatives with antifungal activity. J. Plant Physiol. 162:985-1002.

Selitrennikoff, C. P. (2001). Antifungal proteins. Appl. Environ. Microbiol. 67:2883-2894.

Smith, J. D. (2002). Assessment of spring wheat accessions for disease reaction to Rhizoctonia solani AG-8 in controlled environment and direct seeded field evaluations. Crop Sci. 43:694-700.

Tabei, Y., S. Kitade and Y. Nishizawa (1998). Transgenic cucumber plants harboring a rice chitinase gene exhibit enhanced resistance to gray mold (Botrytis cinerea). Plant Cell Rep.17:159-164.

Takken, F. L. and M. H. Joosten (2000). Plant resistance genes: their structure, function and evolution. Europ. J. Plant Pathol. 106:699-713.

Talbot, N. J., M. J. Kershaw, G. E. Wakley, O. M. H. de Vries, J. G. H. Wessels and J. E. Hamer (1996). MPG1 encodes a fungal hydrophobin involved in surface interactions during infection-related development of Magnaporthe grisea. Plant Cell 8:985-999.

Thompson, C., J. M. Dunwell, C. E. Johnstone, V. Lay, J. Ray, M.
Schmitt and G. Nisbet (1995). Degradation of oxalic acid by transgenic oilseed rape plants expressing oxalate oxidase. Euphytica 85:169-172.

Van Der Vossen, E., A. Sikkema, B. T. L. Hekkert, J. Gros, P. Stevens, M. Muskens, D. Wouters, A. Pereira, W. Stiekema and S. Allefs (2003). An ancient $R$ gene from the wild potato species Solanum bulbocastanum confers broad-spectrum resistance to Phytophthora infestans in cultivated potato and tomato. Plant J. 36:867-882.

Van Der Vossen, E., J. Gros, A. Sikkema, M. Muskens, D. Wouters, P. Wolters, A. Pereira and S. Allefs (2005). The Rpi-blb2 gene from Solanum bulbocastanum is an Mi-1 gene homolog conferring broad-spectrum late blight resistance in potato. Plant J. 44:208-222.

Van Loon, L. C. and E. A. Van Strien (1999). The families of pathogenesis-related proteins, their activities, and comparative analysis of PR-1 type proteins. Physiol. Mol. Plant Pathol. 55:85-97.

Walton, J. (1994). Deconstructing the cell wall. Plant Physiol. 104:1113-1118.

Wani, S. H. and G. S. Sanghera (2010). Genetic engineering for viral disease management in plants. Notulae Scientia Biologicae (In press)

Wu, G. B., J. Shortt, E. B. Lawerence, E. B. Levine, K. C. Fitzsimmons and D. M. Shah (1995). Disease resistance conferred by expression of a gene encoding $\mathrm{H}_{2} \mathrm{O}_{2}$-generating glucose oxidase in transgenic potato plants. Plant Cell. 7:1357-1368

Yamamoto, T., H. Iketani and H. Ieki (2000). Transgenic grapevine plants expressing a rice chitinase with enhanced resistance to fungal pathogens. Plant Cell Rep.15:639-646.

Yang, C. Y., Y. C. Hoa, J. C. Panga, S. S. Huang and J. S. M. Tschen (2009). Cloning and expression of an antifungal chitinase gene of a novel Bacillus subtilis isolate from Taiwan potato field. Biores Technol. 100:1454-1458.

Zhu, Q., E. A. Maher, S. Masoud, R. A. Dixon and C. J. Lamb (1994). Enhanced protection against fungal attack by constitutive co-expression of chitinase and glucanase genes in transgenic tobacco. Bio-Technology 12:807-812. 